Buenos Aires: 400 Years 
THIS PAGE INTENTIONALLY LEFT BLANK 


\section{Buenos Aires: 400 Years}

Edited by Stanley R. Ross and Thomas F. McGann

$\checkmark$ University of Texas Press, Austin 
Copyright $(\mathcal{C} \mathrm{I} 982$ by the University of Texas Press

All rights reserved

Printed in the United States of America

First Edition, 1982

Requests for permission to reproduce material from this work should be sent to Permissions, University of Texas Press, Box 7819, Austin, Texas 787 I 2.

Library of Congress Cataloging in Publication Data

Main entry under title:

Buenos Aires, 400 years.

Includes index.

I. Buenos Aires (Argentina)-Addresses, essays, lectures.

I. Ross, Stanley Robert, I92 I - . II. McGann, Thomas Francis, I920- . III. Title: Buenos Aires, four hundred years.

F3OOI.B98393 982'.I I 82-6903

ISBN 0-292-70738-X AACR2 
The editors dedicate this volume to the memory of James R. Scobie, whose extraordinary contributions to the historiography of Argentina and of Buenos Aires were noted at this conference. 
THIS PAGE INTENTIONALLY LEFT BLANK 